\title{
FSHR Gene Polymorphisms Causes Male Infertility
}

\author{
Ievgeniia Zhylkova1,2, Oleksandr Feskov', Olena Fedota ${ }^{2}$ \\ ${ }^{1}$ IVF Department, Center of Human Reproduction “Clinic of Professor Feskov A. M.", Kharkiv, Ukraine \\ ${ }^{2}$ Department of General Practice-Family Medicine, School of Medicine, V. N. Karazin National University, \\ Kharkiv, Ukraine \\ Email: zhilkova@feskov.com.ua
}

Received 14 January 2016; accepted 1 March 2016; published 4 March 2016

Copyright (C) 2016 by authors and Scientific Research Publishing Inc.

This work is licensed under the Creative Commons Attribution International License (CC BY). http://creativecommons.org/licenses/by/4.0/

(c) () Op Den Access

\begin{abstract}
Prior studies suggested sperm with damaged DNA permits fertilization but may lead to failure of embryo implantation following blastocyst formation. Quantitative correlations between DNA damage and risk of implantation failure have, however, so far not been performed. The aim of this study was to investigate two FSHR gene polymorphisms G919A (Ala307Thr) and A2039G (Asn680Ser) in Eastern Ukrainian Caucasian men with abnormally low fertility. The molecular genetic analysis was performed by real-time PCR, with the level of DNA fragmentation measured by the sperm chromatin dispersion (SCD) method. The relationship between DNA fragmentation in sperm and these genetic polymorphisms was estimated. Compared to homozygotes, the risk of high-level DNA fragmentation ( $>20 \%$ ) increased in men up to age 35 years 16-fold for heterozygotes GA of polymorphic variant G919A, 28-fold for homozygotes AA of polymorphic variant G919A; and 16-fold for heterozygotes GG of polymorphic variant A2039G. A statistically significant positive correlation between number of alternative alleles of the FSHR gene in genotype and degree of DNA fragmentation is proved $\left(r_{s}=0.70, P<0.01\right)$.
\end{abstract}

\section{Keywords}

DNA Fragmentation, FSHR, G919A, A2039G, Male Fertility

\section{Introduction}

In developed countries, $10 \%$ - 15\% of married couples encounter infertility. Up to $50 \%$ of all infertility occurs in the male, while approximately $20 \%$ of cases have male as well as female causes [1] [2]. Approximately $32 \%$ of male factors are believed to be genetic in nature [3] [4]. 
DNA fragmentation is defined as diminished or essential absence of chromatin compaction in nuclei of spermatozoa, and has for years been under investigation as a possible cause of reduced male fertility [5]-[7]. Sperm maturation failures can cause DNA breaks during spermatogenesis, which are apparent in ejaculated sperm. Controlling gene mutations for stages of spermatogenesis can, therefore, lead to minor abnormalities in semen motility/morphology and function to complete absence of cells in seminiferous tubules (sertoli cell only syndrome) [8].

Follicle stimulating hormone (FSH), luteinizinghormone ( $\mathrm{LH})$ and testosterone are the major hormones influencing sperm formation/maturation. FSH does not induce the process of spermatogenesis, but is necessary for formation of mature spermatozoa, with the FSH beta-subunit, known as the follicle stimulating hormone gene beta polypeptide (FSHB, 11p13) determining reproductive function [9] [10]. The follicle stimulating hormone receptor gene (FSHR, 2p21), located on the surface of cells of ovaries and testicles, defines the receptor response to FSH [11].

Almost 150 polymorphic variants of the FSHR gene are currently under investigation in men and women. Polymorphisms of the FSHR gene have been associated with increases of FSH, decreases of progesterone and with decreasing sperm concentrations in semen; effects of single nucleotide polymorphisms (SNP) have also been investigated [12]-[16]. Specifically, variants G919A and A2039G, located in exon 10 of the FSHR gene, have been studied in regard to regulation of spermatogenesis, ovarian follicle development and estrogen synthesis [17].

The aim of this study was to investigate two FSHR gene polymorphisms G919A (Ala307Thr) and A2039G (Asn680Ser) in Eastern Ukrainian Caucasian men with abnormally low fertility.

\section{Materials and Methods}

This study was performed at the Center of Human Reproduction (“Clinic of Professor Feskov,” Kharkov, Ukraine). In the study, all included patients signed an informed consent. The Institutional Review Board of the center approved both the study protocol and informed consent. Seventy-one couples with diagnosis of male factor infertility participated in the study between $4^{\text {th }}$ quarter 2013 and $2^{\text {nd }}$ quarter 2014 . Blood (10 ml) of the 71 men (ages 22 - 45 years) was obtained via routine draw for karyotyping and molecular genetic analysis. In 11 azoospermic patients, there was no semen evaluation possible.

Chromosomes samples for cytogenetic analyses were obtained from peripheral blood lymphocytes via Giemsa banding (G-banding, GTG), and results were presented following the International System of Human Cytogenetic Nomenclature [18]. Using standard techniques [19]-[21], DNA extraction was performed with extractionkits (Macherey-Nagel, NucleoSpin ${ }^{\circledR}$ Blood, Germany). Real-time PCR was done with the ABI PRISM 7500 real-time PCR system (USA), and SNPs determinations in the FSHR gene were performed with Applied BioSystem kits (USA). Sperm DNA fragmentation analysis was performed using sperm chromatin dispersion (SCD, Halotech, HaloSperm, Spain), and data were collected and analyzed with the software Lucia FISH (LIM, Czech Republic). Criteria of the European Association of Urologists suggest that no more than $20 \%$ of an ejaculate should demonstrate damaged DNA [22]. This 20\% threshold criterion was, therefore, selected to differentiate normal versus abnormal on here presented data.

Since distribution of frequencies in data sets for alternative alleles did not follow a Gaussian distribution, non-parametric methods were utilized for statistical analyses. Frequency differences in genotypes were compared by Fischer's test. Relationships between variables were examined by correlation analyses. Verifications of associations of alleles/genotypes and of equality of distributions were accomplished by the Chi-square test $\chi^{2}$ test) at significance levels of $\mathrm{P}=0.05, \mathrm{P}=0.01$ and $\mathrm{P}=0.001$, and odds ratios (OR) and confidence interval (CIs) were calculated [23].

\section{Results and Discussion}

\subsection{Pre-IVF Genetic Observations}

As already noted, 11 of 71 males were azoospermic. Among those, three were heterozygous for the delF508 mutation in the CFTR gene, and three others demonstrated karyotype abnormalities $\{45, \mathrm{XY}$, rob (13;21) (q10;q10); 47, XXY [18]/46, XY [2]; and 47, XXY\}. Seven of 11 patients had alternative polymorphic variant of the FSHR gene. Though the number of azoospermic males was insufficient to reach statistically-valid conclu- 
sions about the relevance of FSHR gene polymorphisms in association with azoospermia, observed excess of homozygotes and deficiency of heterozygotes of polimorphic variants of the FSHR gene may, nevertheless, suggest that locus status might denote increased azoospermia. Confirmation of this hypothesis will, however, require larger numberd of proband. s will, however, be required in future studies to confirm the hypothesis that FSHR polymorphism's influence azoospermia.

Interestingly, all 60 remaining study patients, who produced sperm and did undergo DNA fragmentation assessments, demonstrated normal 46, XY karyotypes. Since age impacts the level of sperm DNA fragmentation, we restricted the remaining investigations to 51 of these 60 men, who were under the age of 35 years at time of study [24] [25]. As Table 1 and Table 2 demonstrate, alleles and genotype frequencies of investigated polymorphic variants of the FSHR gene did not differ under and above age 35 years or in men with azoospermia.

Based on allele frequencies, we calculated the theoretical number of genotypes for a randomly mating population: The actual distribution of genotypes of the polymorphic variant G919A did not statistically differ from the theoretically expected one at equilibrium: $\mathrm{N}\left(\mathrm{df}=2, \chi_{x t}^{2}=5.99, \chi_{\text {actual }}^{2}=4.56, \mathrm{P}>0.05\right)$ and $\mathrm{n}(\mathrm{df}=2$, $\chi_{\text {standard }}^{2}=5.99, \quad \chi_{\text {actual }}^{2}=2.28, \mathrm{P}>0.05$ ).

The actual distribution of genotypes of the polymorphic variant A2039G was also not significantly different from what was theoretically expected at equilibrium in the group of younger patients below age $35(\mathrm{n}=51, \mathrm{df}=$ $\left.2, \chi_{x t}^{2}=5.99, \chi_{\text {actual }}^{2}=3.69, \mathrm{P}>0.05\right)$; it was, however, significantly different for the total group $(\mathrm{n}=71, \mathrm{df}=2$, $\left.\chi_{x t}^{2}=5.99, \chi_{\text {actual }}^{2}=6.72, \mathrm{P}<0.05\right)$, though even the total group demonstrated no statistically significant differences in frequencies of genotypes. $\mathrm{AG}_{\text {actual }}-26.8 \%$ and $\mathrm{AG}_{\text {theor }}-38.0 \%\left(\mathrm{df}=140, \mathrm{t}_{\mathrm{st}}=1.98, \mathrm{t}_{\text {actual }}=1.61, \mathrm{P}>\right.$ 0.05 ) is one example. The obtained data are present in Table 1.

The relationship between DNA fragmentation in sperm and these genetic polymorphisms was estimated. Among 51 younger probands with different genotypes, DNA fragmentation, however, those with alternatively homozygous or heterozygous alleles was significantly higher than is those with homozygotes alleles in that

Table 1. Alleles frequencies of polymorphic variants G919A and A2039G of FSHR gene in total $(\mathrm{N}=71)$ and younger $(\mathrm{n}=$ 51) groups.

\begin{tabular}{|c|c|c|}
\hline \multirow{2}{*}{ Polymorphism } & \multicolumn{2}{|c|}{ Alleles frequencies } \\
\hline & Total group, $\mathrm{N}=71$ & Younger group ( $<35$ y.o.), $n=51$ \\
\hline G919A & $P_{G}=0.697, q_{A}=0.303$ & $P_{G}=0.726, q_{A}=0.275$ \\
\hline A2039G & $P_{A}=0.739, q_{G}=0.261$ & $P_{A}=0.775, q_{G}=0.225$ \\
\hline Statistics (G919A) & $\mathrm{df}=2, \quad \chi_{x t}^{2}=5.99, \quad \chi_{\text {actual }}^{2}=4.56, \mathrm{P}>0.05$ & $\mathrm{df}=2, \quad \chi_{\text {standard }}^{2}=5.99, \quad \chi_{\text {actual }}^{2}=2.28, \mathrm{P}>0.05$ \\
\hline Statistics (A2039G) & $\mathrm{df}=2, \quad \chi_{x t}^{2}=5.99, \quad \chi_{\text {actual }}^{2}=6.72, \mathrm{P}<0.05$ & $\mathrm{df}=2, \quad \chi_{x t}^{2}=5.99, \quad \chi_{\text {actual }}^{2}=3.69, \mathrm{P}>0.05$ \\
\hline
\end{tabular}

Table 2. Distribution of genotypes of polymorphic variants A2039G, G919A of the FSHR gene in total $(\mathrm{N}=71)$ and younger $(n=51)$ groups.

\begin{tabular}{|c|c|c|c|c|c|}
\hline \multirow{3}{*}{ SNP } & \multirow{3}{*}{ Genotypes } & \multicolumn{4}{|c|}{ Distribution } \\
\hline & & \multicolumn{2}{|c|}{ Total group, N, \% } & \multicolumn{2}{|c|}{ Younger group (<35 y.o.), n, \% } \\
\hline & & Actual & Theoretical & Actual & Theoretical \\
\hline \multirow{3}{*}{ A2039G, N (\%) } & AA & $43(60.6)$ & $39(55.0)$ & $33(64.7)$ & $30(60.0)$ \\
\hline & AG & $19(26.8)$ & $27(38.0)$ & $13(25.5)$ & $18(35.0)$ \\
\hline & GG & $9(12.6)$ & $5(7.0)$ & $5(9.8)$ & $3(5.0)$ \\
\hline \multirow{3}{*}{ G919A, N (\%) } & GG & 38 (53.5) & 35 (49.3) & 29 (56.9) & $27(52.7)$ \\
\hline & GA & $23(32.4)$ & $30(42.2)$ & $16(31.2)$ & 20 (39.9) \\
\hline & AA & $10(14.1)$ & $6(8.5)$ & $6(11.9)$ & $4(7.4)$ \\
\hline Statistics (A2039G) & $\mathrm{df}=2, \quad \chi_{x t}^{2}$ & $=2.73, \quad \chi_{\text {actual }}^{2}=$ & $>0.05$ & $\mathrm{df}=2, \quad \chi_{x t}^{2}=1.45, \quad \chi_{\text {actual }}^{2}$ & $=5.99, \mathrm{P}>0.05$ \\
\hline Statistics (G919A) & $\mathrm{df}=2, \quad \chi_{x t}^{2}$ & $=2.05, \quad \chi_{\text {actual }}^{2}=$ & $>0.05$ & $\mathrm{df}=2, \quad \chi_{x t}^{2}=0.92, \quad \chi_{\text {actual }}^{2}$ & $=5.99, \mathrm{P}>0.05$ \\
\hline
\end{tabular}


DNA fragmentation in the former group exceeded the threshold level of $20.0 \%$ more often $\mathrm{P}<0.001$ (Table 2 and Table 3).

Average sperm DNA fragmentation in homozygotes with basic alleles GG $(11.7 \% \pm 5.7 \%)$ and in heterozygotes GA $(26.2 \% \pm 8.8 \%)$ with polymorphic variant G919A were also statistically different (Mann-Whitney U test: $\mathrm{U}_{\text {critical }}=149, \mathrm{U}_{\text {actual }}=68$; $\mathrm{P}<0.01$; Table 4). Significant differences in fragmentation levels were also apparent in homozygotes with basic alleles AA $(13.9 \% \pm 6.9 \%)$ and heterozygotes AG $(25.6 \% \pm 8.4 \%)$, and in the polymorphic variant A2039G $\left(\mathrm{U}_{\text {crilical }}=120, \mathrm{U}_{\text {actual }}=87.5, \mathrm{P}<0.01\right.$; Table 4). We also noted a statistically significant positive correlation between number of alternative alleles of the FSHR gene in genotype and degree of DNA fragmentation (Spearman correlation $\mathrm{r}_{\mathrm{s}}=0.70 \pm 0.10, \mathrm{P}<0.01$; Table 4).

These findings can be summarized as demonstrating that in comparison to homozygotes with basic alleles, the heterozygotes GA with polymorphic variant G919A show a 16-fold greater risk of high level DNA fragmentation $(\mathrm{OR}=15.83,95 \%$ CI $3.50-71.54, \mathrm{P}<0.05)$, while the homozygotes AA show a 28-fold risk $(\mathrm{OR}=27.76$, 95\% CI 3.33 - 231.70, P < 0.05). For heterozygotes AG and homozygotes GG with polymorphic variant A2039G, the risk of developing a higher level of DNA fragmentation was 16 -fold greater (OR $=15.55,95 \% \mathrm{CI}$ $3.42-70.76, \mathrm{P}<0.05$; OR $=15.55,95 \%$ CI $1.98-122.15, \mathrm{P}<0.05$, respectively) when compared to homozygotes having only basic allele.

\subsection{Relevance of Pre-IVF Hormonal Levels}

We tried to evaluate the levels of FSH and testosterone for patients in the study. 26 patients with basic GGAA alleles demonstrated FSH levels of $9.49 \pm 2.61 \mathrm{mIU} / \mathrm{mL}$ and testosterone levels of $25.48 \pm 5.49 \mathrm{nmol} / \mathrm{L}$. FSH level was, thus, approximately $30 \%$ below what is considered the median 12.5 of normal range $5.0-20.0 \mathrm{mIU} /$ $\mathrm{mL}$, while average testosterone of basic allele patients was practically equal to the median 25.2 within the normal

Table 3. DNA fragmentation in sperm of different genotypes of polymorphic variant of G919A and A2039G of the FSHR in younger group (<35 y.o.), $(n=51)$.

\begin{tabular}{|c|c|c|c|c|c|}
\hline SNP & Genotypes & N (\%) & Average age, $\mathrm{x} \pm \mathrm{mx}$ & $\begin{array}{l}\text { DNA fragmentation } \\
\text { level, \% }\end{array}$ & $\begin{array}{c}\text { Number of patients with DNA } \\
\text { fragmentation level }>20 \%\end{array}$ \\
\hline \multirow{3}{*}{ G919A } & GG & $29(56.9)$ & $30.2 \pm 2.5$ & $11.7 \pm 5.7$ & $3\left(10.3^{*}\right)$ \\
\hline & GA & $16(31.2)$ & $30.6 \pm 1.8$ & $26.2 \pm 8.8$ & $11\left(68.8^{*}\right)$ \\
\hline & AA & $6(11.9)$ & $31.8 \pm 2.6$ & $36.5 \pm 16.2$ & $5(83.3)$ \\
\hline \multirow{3}{*}{ A2039G } & AA & $33(64.7)$ & $30.1 \pm 2.3$ & $13.9 \pm 6.9$ & $5\left(15.2^{* *}\right)$ \\
\hline & AG & $13(25.5)$ & $31.3 \pm 2.2$ & $25.6 \pm 8.4$ & $10\left(76.9^{* *}\right)$ \\
\hline & GG & $5(9.8)$ & $31.4 \pm 2.7$ & $39.3 \pm 17.2$ & $4(80)$ \\
\hline \multicolumn{2}{|c|}{ Statistics } & & $\begin{array}{l}{ }^{*} \mathrm{df}=2, \quad \chi_{x t}^{2} \\
{ }^{* *} \mathrm{df}=2, \quad \chi_{x}^{2}\end{array}$ & $\begin{array}{l}3.82, \chi_{\text {actual }}^{2}=16.41, \\
3.82, \chi_{\text {actual }}^{2}=16.19,\end{array}$ & 0.001 \\
\hline
\end{tabular}

Table 4. DNA fragmentation in the sperm of patients with different genotypes of polymorphic variants G919A and A2039G of FSHR gene in younger group (<35 y.o.), $(\mathrm{n}=51)$.

\begin{tabular}{ccccc}
\hline Genotypes & Quantity & Average age, $\mathrm{x} \pm \mathrm{mx}$ & $\begin{array}{c}\text { DNA fragmentation } \\
\text { level, } \%\end{array}$ & $\begin{array}{c}\text { Number of patients with DNA } \\
\text { fragmentation level }>20 \%\end{array}$ \\
\hline GGAA & 26 & $29.9 \pm 2.5$ & $10.7 \pm 5.1$ & $1(3.9 \%)$ \\
GGAG & 3 & $32.7 \pm 1.8$ & $20.3 \pm 7.1$ & $2(66.7 \%)$ \\
GAAA & 6 & $30.5 \pm 1.2$ & $24.5 \pm 8.7$ & $3(50.0 \%)$ \\
GAAG & 10 & $30.6 \pm 2.2$ & $27.6 \pm 8.6$ & $1(80.0 \%)$ \\
AAAA & 1 & $34.0 \pm 0.0$ & $22.5 \pm 0.0$ & $4(80.0 \%)$ \\
AAGG & 5 & $31.4 \pm 2.7$ & $39.3 \pm 17.2$ & \\
Statistics & & (Spearman correlation) df $=3, \mathrm{rs}=0.70 \pm 0.10, \mathrm{P}<0.01$ & \\
\hline
\end{tabular}


range 12.1 - $38.3 \mathrm{nmol} / \mathrm{L}$. Analysis revealed that our cohort of 51 patients is not large enough for statistically significant conclusions, but certain polymorphism-related deviations of hormonal level of polymorphic patients were observed in comparison with patients having basic allele of FSHR gene. For example, among 10 patients with GAAG polymorphism, the hormonal levels were FSH = $12.66 \pm 8.55$ and testosterone = 18.92 \pm 3.50 ; i.e. their average FSH was 33.4\% exceeding basic allele's one (9.49), but close to normal median, while average testosterone was $34.7 \%$ below basic allele's one.

\subsection{Post-IVF Comparative Observations}

After certain preparatory treatment, near dozen of all 51 couples entered the IVF cycles. At that, compare with patients having polymorphic abnormalities of FSHR gene, for the couples having basic FSHR gene allele, we observed not only the easy obtaining of good quality blastocysts, but also a better success rate of embryo implantation. However, a small size of patient group in the study does not allow making any statistically significant conclusions.

\subsection{Expectations Prior Statistically Significant Observations}

Among 51 couples with male factor infertility in the study, there were 26 male patients with basic allele of FSHR gene and 25 patients with polymorphic abnormality in said gene. This allows us to assume that near $50 \%$ (but not less than 10\%) of infertile men might express a polymorphic variant of the FSHR gene. Another assumption is about obtaining of blastocyst of good quality in IVF cycle. Based on our limited observations in the small-size study, we may expect that in a large-cohort study all basic-allele patients will easy obtain good quality blastocysts in sufficient amount, while only part of polymorphic patients will also be capable to do so. Third important assumption includes the expectation that both quality of blastocyst and probability of success of embryo implantation depends on specific type of polymorphism.

For confirmation of our hypothesis with statistical significance, we may suggest a retrospective analysis of the human genomic samples that accumulated in specialized laboratories. For example, Affiliated Genetics Inc. (Salt Lake City, UT) holds a multi-thousand sample bank and collaborates with IVF clinics nationwide; this allows producing a statistically significant analysis of correlation of FSHR gene polymorphism (FGP) with outcome of IVF treatment for the cycles that have been already performed.

Ahead of completion of retrospective analysis, we may speculate that the applying of pre-IVF diagnostic on FGP-presence in male patient with further PGD-selection of the embryo, which has no such genetic abnormality as FGP, can not only lead to increase of implantation success rate, but also eliminate the risk of FGP-related infertility in genetic successor despite presence of FGP in the father's genome.

\section{Conclusions}

Normal function of cells involved in spermatogenesis, including production of FSH by these cells, is dependent on the expression of the FSH receptor (FSHR). A better understanding of factors important for FSHR gene transcription is, therefore, potentially important for finding ways to either modulate endocrine regulation or cellspecific gene expression, thereby preventing and/or treating the risk of infertility. Some polymorphism can be assumed to affect the gene's transcription and, therefore, effects. However, the impact of FSHR variants, including single nucleotide polymorphisms (SNPs) on male fertility is currently not yet well understood.

Reported results have been contradictory: Some studies did not observe significant differences of FSH level in serum of normal and infertile patients, reaching the conclusion that SNP distribution does not matter for male reproductive function [24]-[28]. Other investigations, however, found significant variations of SNP distributions, and suggested that ethnic differences could be involved in polymorphism-related infertility [29]-[32]. In some previous studies, the G-29-A919-A2039 haplotype was shown to be more prevalent in normozoospermic men than in azoospermic patients (38.4\% vs. 33.9\%, respectively; chi (2) test, $\mathrm{P}=0.045$ ), indicating that this haplotype may be a protective factor against male sterility [33]. Quantitatively measurable parameters in reference to genetic abnormalities have, however, so far only sparsely investigated. We previously reported that in men over age 35 sperm fragmentation appears increased [34].

Here we went beyond those investigations: Based on the criteria set by the European Association of Urologists, suggesting that to be normally fertile, no more than $20 \%$ of the ejaculate should demonstrate damaged 
DNA, we investigated the DNA damage's associations with specific polymorphisms in the FSHR gene among male patients with reduced fertility. To avoid previously noted suspicions that ethnic backgrounds may affect these associations, we performed this study in a genetically homogenous population of Caucasian Ukrainians. Furthermore, in order to eliminate reported age-dependent associations, we concentrated on a younger patient subgroup under age 35 years.

In this, therefore, very homogenous study group we detected statistically significant difference in DNA fragmentation levels between homozygotes with basic alleles GG and heterozygotes GA of polymorphic variant G919A of FSHR gene, and between homozygotes with basic alleles AA and heterozygotes AG for polymorphic variant A2039G of FSHR gene. The observed associations suggest that FSHR gene expression might influence the process of chromatin compaction in sperm nuclei and, consequently, affect quality of sperm and, therefore, male fertility.

Our data, therefore, demonstrate that FSHR gene polymorphisms seem to have a direct influence on spermatogenesis, and that certain polymorphisms, therefore, might contribute to multi-genetic male infertility. These observations, therefore, confirm previous qualitative hypotheses [35]-[41].

If confirmed by further studies, these results also suggest that here reported genetic associations might be used clinically to prospectively assess risk toward male infertility. We here, thus, for the first time demonstrated quantitatively that alternative alleles of polymorphic variants G919A and A2039G of the FSHR gene might represent increased risk for high-level DNA fragmentation ( $>20 \%)$ in sperm of young men up to age 35, who present with reduced fertility. These observations advance our understanding of potential genetic causes of selected cases of male infertility, which previously have not been understood in their etiologies. Once confirmed, these data suggest that DNA fragmentation in selected cases of presumed male infertility may be indicated in association with determinations of FSHR gene polymorphisms.

If future observations statistically significantly confirm our hypothesis regarding the influence of FSHR male polymorphism (through spermatogenesis and embryogenesis) both on blastocyst formation and embryo transfer success, we may predict that the prescreening of embryo's FSHR gene code prior ET will increase pregnancy rate, and, therefore, such prescreening will be recommended in IVF for infertile men expressing FSHR polymorphism. Further research on influence of FSHR female polymorphism on embryogenesis is also suggested in this regard.

\section{References}

[1] Vartanian, E.V., Petrin, A.N. and Kurnosov, T.R. (2010) Genetic Factors of Male Infertility. Problems of Reproduction, 2, 74-78.

[2] Dohle, G.R., Diemer, T., Giwercm, A., Jungwirth, A., Kopa, Z. and Krausz, C. (2010) Male Infertility. Scientific Editing: Hakobyan, A.S., European Association of Urology.

[3] Fedorov, I.D. and Kuznetsova, T.V. (2007) Genetic Factors of Male Infertility. Journal of Obstetrics and Women's Diseases, 1, 64-72.

[4] Foresta, C., Moro, E. and Ferlin, A. (2001) Y Chromosome Microdeletions and Alterations of Spermatogenesis. Endocrine Reviews, 22, 226-239. http://dx.doi.org/10.1210/er.22.2.226

[5] Zhylkova, I., Feskov, O., Feskova, I., Fedota, O. and Feskov, V. (2014) Sperm DNA Fragmentation as a Factor of Male Low Reproductive Function in IVF Practice. International Journal of Biology, 6, 75-81.

[6] Vorobieva, O.A., Voskresenskaya, A.V., Odintsov, A.A. and Filatov, M.V. (2005) Male Infertility and the Violation of the Structural Organization of Chromatinsperm. Is There a Connection? Problems of Reproduction, 6, 56-62.

[7] Cayli, S., Sakkas, D., Vigue, L., Demir, R. and Huszar, G. (2004) Cellular Maturity and Apoptosis in Human Sperm: Creatin Kinase, Caspase-3 and Bcl-XL Levels in Mature and Diminished Maturiry Sperm. Molecular Human Reproduction, 10, 365-372. http://dx.doi.org/10.1093/molehr/gah050

[8] Henkel, R., Kierspel, E., Hajimohammad, M., Stalf, T., Hoogendijk, C., Mehnert, C., Menkveld, R., Schill, W. and Kruger, T.F. (2003) DNA Fragmentation of Spermatozoa and Assisted Reproduction Technology. Reproductive BioMedicine Online, 7, 477-484. http://dx.doi.org/10.1016/S1472-6483(10)61893-7

[9] Hong, Y., Guoning, H., Yang, G. and De Yi, L. (2006) Relationship between Human Sperm-Hyaluronan Binding Assay and Fertilization Rate in Conventional in Vitro Fertilization. Human Reproduction, 21, 1545-1550. http://dx.doi.org/10.1093/humrep/del008

[10] Tarasova, M.N. (2008) For the Diagnosis of Male Reproductive Disorders. Problems of Reproduction, 5, 52-55.

[11] Plant, T.M. and Marshall, G.R. (2001) The Functional Significance of FSH in Spermatogenesis and the Control of Its 
Secretion in Male Primates. Endocrine Reviews, 22, 764-786. http://dx.doi.org/10.1210/edrv.22.6.0446

[12] Grigorova, M., Punab, M., Poolamets, O., Sõber, S., Vihljajev, V., Žilaitienė, B., Erenpreiss, J., Matulevičius, V., Tsarev, I. and Laan, M. (2013) Study in 1790 Baltic Men: FSHR Asn680Ser Polymorphism Affects Total Testes Volume. Andrology, 1, 293-300. http://dx.doi.org/10.1111/j.2047-2927.2012.00028.x

[13] Gromoll, J., Schüring, A., Busch, A., Kliesch, S. and Tüttelmann, F. (2013) Influence of Variants in the FSHB and FSHR Gene on Reproductive Parameters in Males and Females. Endocrine Abstracts, 32, OC5.4.

[14] Zhylkova, I., Feskov, O., Tischenko, O., Blazhko, O. and Somova, O. (2014) In Male Factor Infertility, the Level of DNA Fragmentation in Sperm Correlates with Polymorphism of Follicle-Stimulating Hormone Receptor. Proceedings of the 30th Annual Meeting of ESHRE, Munich, 29 June-2 July 2014, 18.

[15] Ahmadi, A. and Ng, S.C. (1999) Fertilizing Ability of DNA-Damaged Spermatozoa. Journal of Experimental Zoology, 284, 696-704. http://dx.doi.org/10.1002/(sici)1097-010x(19991101)284:6<696::aid-jez11>3.0.co;2-e

[16] Wu, X.Q., Xu, S.M., Liu, J.F., Bi, X.Y., Wu, Y.X. and Liu, J. (2014) Association between FSHR Polymorphisms and Polycystic ovary Syndrome among Chinese Women in North China. Journal of Assisted Reproduction and Genetics, 31, 371-377. http://dx.doi.org/10.1007/s10815-013-0166-z

[17] Watkins, P.C., Eddy, R., Beck, A.K., Vellucci, V., Leverone, B., Tanzi, R.E., Gusella , J.F. and Shows, T.B. (1987) DNA Sequence and Regional Assignment of the Human Follicle-Stimulating Hormone Beta-Subunit Gene to the Short Arm of Human Chromosome 11. DNA, 6, 205-212. http://dx.doi.org/10.1089/dna.1987.6.205

[18] Shaffer, L.G., Slovak, M.L. and Campbell, L.J. (2009) ISCN 2009. An International System for Human Cytogenetic Nomenclature. S. Karger Publishers Inc., Basel.

[19] Minegishi, T., Nakamura, K., Takakura, Y., Ibuki, Y. and Igarashi, M. (1991) Cloning and Sequencing of Human FSH Receptor cDNA. Biochemical and Biophysical Research Communications, 175, 1125-1130.

http://dx.doi.org/10.1016/0006-291X(91)91682-3

[20] Dolgov, V.V., Lugovskaya, S.A., Fanchenko, N.D., et al. (2006) Laboratory Diagnosis of Male Infertility. Moscow.

[21] Aittomaki, K., Lucena, J.L.D., Pakarinen, P., Sistonen, P., Tapanainen, J., Gromoll, J., Kaskikari, R., Sankila, E.M., Lehvaslaiho, H., Engel, A.R., Nieschlag, E., Huhtaniemi, I. and de la Chapelle, A. (1995) Mutation in the FollicleStimulating Hormone Receptor Gene Causes Hereditary Hypergonadotropic Ovarian Failure. Cell, 82, 959-968. http://dx.doi.org/10.1016/0092-8674(95)90275-9

[22] Jungwirth, A., Diemer, T., Dohle, G.R., Giwercman, A., Kopa, Z., Krausz, C. and Tournaye, H. (2012) European Association of Urology Guidelines on Male Infertility. European Urology, 62, 324-332.

[23] Atramentova, L.A. and Utyevska, A.M. (2007) Statistical Methods in Biology. Kharkiv.

[24] Smit, M., Romijn, J.C., Wildhagen, M.F., Veldhoven, J.L.M., Weber, R.F.A. and Dohle, G.R. (2010) Decreased Sperm DNA Fragmentation after Surgical Varicocelectomy Is Associated with Increased Pregnancy Rate. Journal of Urology, 183, 270-274. http://dx.doi.org/10.1016/j.juro.2009.08.161

[25] Agarwal, A. and Said, T.M. (2003) Role of Sperm Chromatin Abnormalities and DNA Damage in Male Infertility. Human Reproduction, 19, 331-345. http://dx.doi.org/10.1093/humupd/dmg027

[26] Tapanainen, J.S., Aittomaki, K., Min, J., Vaskivuo, T. and Huhtaniemi, I.T. (1997) Men Homozygous for an Inactivating Mutation of the Follicle-Stimulating Hormone (FSH) Receptor Gene Present Variable Suppression of Spermatogenesis and Fertility. Nature Genetics, 15, 205-206. http://dx.doi.org/10.1038/ng0297-205

[27] Livshits, A.B., Kravchenko, S.A., Tatarsky, P.F., Sudoma, I.A. and Livshits, L.A. (2008) Molecular Genetic Studies of Disturbances of Natural and Induced Ovulation. Cytology and Genetics, 42, 63-69.

[28] Kurilo, L.F., Shileiko, L.V., Sorokina, T.M. and Grishina, E.M. (2000) The Structure of Inherited Disorders of the Reproductive System. WestRAMS, 5, 32-36.

[29] Asatiani, K., Gromoll, J., Eckardstein, S.V., Zitzmann, M., Nieschlag, E. and Simoni, M. (2002) Distribution and Function of FSH Receptor Genetic Variants in Normal Men. Andrologia, 34, 172-176. http://dx.doi.org/10.1046/j.1439-0272.2002.00493.x

[30] Pengo, M., Ferlin, A., Arredi, B., Ganz, F., Selice, R. and Garolla, A. (2006) FSH Receptor Gene Polymorphisms in Fertile and Infertile Italian Men. Reproductive BioMedicine Online, 13, 795-800. http://dx.doi.org/10.1016/S1472-6483(10)61026-7

[31] Shimoda, C., Koh, E., Yamamoto, K., Matsui, F., Sugimoto, K. and Sin, H.S. (2009) Single Nucleotide Polymorphism Analysis of the Follicle-Stimulating Hormone (FSH) Receptor in Japanese with Male Infertility: Identification of Codon Combination with Heterozygous Variations of the Two Discrete FSH Receptor Gene. Endocrine Journal, 56, 859865. http://dx.doi.org/10.1507/endocrj.K09E-130

[32] Laven, J.S.E., Mulders, A.G.M.G.J., Suryandari, D.A., Gromoll, J., Nieschlag, E., Fauser, B.C. and Simoni, M. (2003) Follicle-Stimulating Hormone Receptor Polymorphisms in Women with Normogonadotropic Anovulatory Infertility. 
Fertility and Sterility, 80, 986-992. http://dx.doi.org/10.1016/S0015-0282(03)01115-4

[33] Lend, A.V., Belousova, A., Haller-Kikkatalo, K., Punab, M., Poolamets, O., Peters, M. and Saluments, A. (2010) Follicle-Stimulating Hormone Receptor Gene Haplotypes and Male Infertility in Estonian Population and Meta-Analysis. Systems Biology in Reproductive Medicine, 56, 84-90. http://dx.doi.org/10.3109/19396360903456676

[34] Feskov, O.M., Zhylkova, I.S., Fedota, O.M. and Sotnik, N.N. (2013) Investigation of the Relationship between the Breach of Compaction of Chromatin and the Presence of Aneuploidy in Sperm Nuclei in Men with Reduced Fertility. Bulletin of KNU named after VN Karazina Series: Biology, 1056, 89-94.

[35] Oleszczuk, K., Giwercman, A. and Bungum, M. (2011) Intra-Individual Variation of the Sperm Chromatin Structure Assay DNA Fragmentation Index in Men from Infertile Couples. Human Reproduction, 26, 3244-3248. http://dx.doi.org/10.1093/humrep/der328

[36] Armitage, P. and Berry, G. (1994) Statistical Methods in Medical Research. 3rd Edition, Blackwell Scientific Publications, Oxford.

[37] Seli, E. and Sakkas, D. (2005) Spermatozoa Nuclear Determinants of Reproductive Outcome: Implications for ART. Human Reproduction Update, 11, 337-349. http://dx.doi.org/10.1093/humupd/dmi011

[38] Speyer, B.E., Pizzey, A.R., Ranieri, M., Joshi, R., Delhanty, J.D.A. and Serhal, P. (2012) Fall in Implantation Rates Following ICSI with Sperm with High DNA Fragmentation. Human Reproduction, 25, 1609-1618. http://dx.doi.org/10.1093/humrep/deq116

[39] Tesarik, J., Mendoza, C. and Greco, E. (2002) Paternal Effects Acting during the First Cell Cycle of Human Preimplantation Development after ICSI. Human Reproduction, 17, 184-189. http://dx.doi.org/10.1093/humrep/17.1.184

[40] Simon, L., Brunborg, G., Stevenson, M., Lutton, D., McManus, J. and Lewis, S.E. (2010) Clinical Significance of Sperm DNA Damage in Assisted Reproduction Outcome. Human Reproduction, 25, 1594-1608. http://dx.doi.org/10.1093/humrep/deq103

[41] Calle, J.F., Muller, A. and Walschaerts, M. (2008) Sperm Deoxyribonucleic Acid Fragmentation as Assessed by the Sperm Chromatin Dispersion Test in Assisted Reproductive Technology Programs: Results of a Large Prospective Multicenter Study. Fertility and Sterility, 19, 671-682. 